\title{
Beeldspraak over oorlog en schepping, geweld en geweldloosheid in de Openbaring van Johannes
}

\author{
Paul B Decock \\ St Joseph's Theological Institute, Cedara \\ University of KwaZulu-Natal
}

\begin{abstract}
Images of war and creation, violence and nonviolence in the Revelation of John

Much of the violent imagery of Revelation can be seen as inspired by the image of God as the Divine Warrior who will overcome the chaotic forces threatening creation and who will bring creation to its fulfillment. This violence is reserved for God and the exalted Jesus although the prophetic ministry of churches shares to some extent in this divine power and even in its violence (11:5-6). However, human victory is won through worship of God instead of worship of Satan and the Beast, and through prophetic witness unto death in order to bring the inhabitants of the world to repentance and so to overcome sin that destroys creation. This human victory is made possible by the "blood of Jesus" and requires that his followers persevere in the works of Jesus to the end (2:26) in order to share in the new creation of which Jesus is God's agent from the beginning (3:14).
\end{abstract}

\section{INLEIDING}

Gods heilige oorlog zoals beschreven in het boek Openbaring roept onmiddellijk associaties op met "heilige oorlogen," met de kruistochten, met gedwongen bekeringen, en met alle mogelijke soorten geweld en verwoesting in de naam van God. Hoe kan Openbaring dan het verschijnsel oorlog beschrijven als een scheppend instrument in Gods hand? Is het godsbeeld dat daarin zichtbaar wordt niet dat van een gewelddadige, dictatoriale God?

Het thema van Gods oorlog, of de Chaoskampf, heeft een lange geschiedenis, in de literatuur van Babylon, Ugarit, en Israël. We zullen eerst dit thema onderzoeken in de Bijbelse traditie en in Openbaring. Dit brengt ons dan naar de tegenstelling Lam - Leeuw in Op 5:5-6 en naar de betekenis van de tegenstelling tussen het beeld van de lijdende Jezus gedurende zijn 


\section{Beeldspraak over oorlog en schepping}

aardse leven enerzijds en de strijdende en oordelende hemelse Jezus anderzijds. Zijn aardse leven is gekenmerkt door zijn liefde tot de dood (Op $1: 5-6 ; 5: 9-10,12)$, terwijl hij in zijn hemelse staat, samen met God, voorgesteld wordt als een toornige, vreesaanjagende, strijdende figuur (6:16$17 ; 17: 14 ; 19: 11-16)$. We keren daarna terug naar het beeld van God als de almachtige Schepper die de tegenstanders en vernielers van zijn scheppingswerk door oorlog en oordeel overwint. De vraag is dan, hoe dit goddelijk geweld in het boek Openbaring samengaat met de geweldloosheid van de aardse Jezus en zijn volgelingen.

\section{SCHEPPING ALS OORLOG TEGEN DE CHAOTISCHE MACHTEN IN DE BIJBELSE TRADITIE}

Terwijl het beeld van de pottenbakker totale passiviteit van het gecreëerde oproept (Jes 29:16; 45:9; 64:8; Jer 18:6; Rom 9:21) is er ook het beeld van de overwinning over destructieve machten. In het algemeen wordt in de bijbelse teksten de absolute macht van God en de uiteindelijke machteloosheid van die krachten beklemtoond. ${ }^{1}$ Dit is zeer duidelijk in Genesis $1 .^{2}$ Maar, de verbeelding van God als strijder en de schepping als een strijd tegen de chaotische machten, ook bekend in Ugarit en Babylon, ${ }^{3}$ bleef verder werken in Israël gedurende heel zijn geschiedenis ${ }^{4}$ en werd nog levendiger in de postmonarchische periode, toen de politieke machthebbers ervaren werden als

\footnotetext{
${ }^{1}$ Bij de geboorte van de zee zet God perken: Job 38:8-11; Behemot is een schepsel van God: Job 40:15; zo ook de taninim in Gen 1:21.

2 "In Genesis 1, the waters have not been neutralized but demythologized and even depersonalized. They have not, however, been eliminated. Instead, the process of setting up boundaries and making separations that we have come to call creation forces them to alternate with other elements - the sky (perceived as a kind of sheet of metal stretched out as a vault over the Earth), the atmosphere, the dry land. God has not annihilated the primordial chaos. He has only limited it. The same holds for the other uncreated reality, darkness" (Levenson 1994:122-123).

${ }^{3}$ Zie Levenson (1994:12), "[t]he observation that the Chaoskampf can appear without an acommpanying cosmogony is worth making because it counters the tendency among many scholars to conflate or to homogenize texts and, in the process, to miss changes and developments in the history of the religion. But too much can be made of the distinction between the myth with creation and the myth without creation. Two and a half millennia of Western theology have made it easy to forget that throughout the ancient Near Eastern world, including Israel, the point of creation is not the production of matter out of nothing, but rather the emergence of a stable community in a benevolent and life-sustaining order."

${ }^{4}$ De grote zeemonsters (taninim): Ps 74:12-17; Job 7:12; in Gen 1:21 en Job 40:15-41:26 zijn ze Gods schepsels. Verder is er de diepte, de afgrond, de zee, de wateren (Gen 1:2; 7:11; Ps 74:13; Job 3:8; 7:12); Leviatan (Job 3:8; 26:13; 40:25; Ps 74:14); Rahab (Ps 89:10-11; Job 26:12). Zie Oden (1992); Hiebert (1992).
} 
chaotische krachten. ${ }^{5}$ In deze moeilijke omstandigheden herinnerde men zich God als de schepper en als de overwinnaar van de chaosmonsters, ${ }^{6}$ als de hemelse strijder die het recht handhaaft (Jes 59:15b-20; 63:1-7; Zech 9:1-7; 14:1-21; zie Hiebert 1992:879).

De oorspronkelijke overwinning over de chaotische machten bij de schepping werd niet beschouwd als definitief. Zoals Levenson het uitdrukt: "... the stability of nature is not intrinsic; it is only a corollary of God's faithfulness" (1994:14). Dit wordt op dramatische wijze geïllustreerd in het verhaal van de zondvloed, waar God besluit om de chaos te laten terugkeren en de schepping ongedaan te maken vanwege de slechtheid van de mensen (Gen $6: 5 ; 7: 11$ ). Menselijke slechtheid als deelname aan de chaotische machten brengt de schepping in gevaar. ${ }^{7}$ Terwijl er teksten zijn die een soort natuurlijke correlatie zien tussen menselijke zondigheid en natuurrampen en tussen rechtvaardigheid en het welzijn van de schepping (1 En 80:2-8; 100:10-13), zijn er ook heel wat teksten die dit verband toeschrijven aan God, aan wie alleen de mens verantwoordelijkheid verschuldigd is en aan wie de natuur onderworpen is (Patai 1976:145). Menselijke ontrouw wordt dan gezien als een fundamentele bedreiging van de schepping omdat God's trouw in gevaar komt. In die zin is gerechtigheid de sleutel tot het welzijn van de aarde. ${ }^{8}$

Aan het einde van het verhaal over de zondvloed komt er echter een nieuw element bij: God sluit een verbond met Noach en verbindt zich ertoe de aarde nooit meer te laten terugglijden in de chaos (Gen 9:8-17). ${ }^{9}$ Gods trouw zal sterker zijn dan alle mogelijke menselijke ontrouw. In omstandigheden

\footnotetext{
${ }^{5}$ Zie het werk van Hanson (1971; 1976 en in het biezonder 1975:300-323). Hiebert (1992:879) verwijst naar 2 Makk 10:28-31; 11:6-12; zie ook 5:1-4, waar men God ziet als iemand die vecht aan de zijde van de Makkabeeën. Dan 7-12 geeft de indruk dat het is God alleen die vecht, terwijl de menselijke bijdrage bestaat in getrouwheid aan God en passieve weerstand tegen de politieke machten.
}

${ }^{6}$ Zie Jes 27:1,12-13; 51:9-10; Ezek 29:3-5; 32:4; Dan 7; Op 13:1-2; 1 En 60:7-1, 24; 4 Ez 6:49-52; 2 Bar 29:4.

${ }^{7}$ De chaotische machten zijn effectief op drie gebieden: als primordiaal zoals de Zee, Leviatan, etc; als historische volken (Amalek, Gog, Babylon, Egypte) en in het hart van de mensen. Voor Middleton (2004:348-352) houdt dit beeld van de schepping een etisch problem in: "Creation-by-combat ... ontologizes evil, and assumes it is equally primordial with God and goodness. It may even be more primordial ..." (Middleton 2004:350). Dit is echter maar een probleem geworden na de periode van het NT, een probleem waarop de leer van de creatio ex nihilo een antwoord werd.

${ }^{8}$ De band tussen gerechtigheid en het welzijn van de aarde is regelmatig te vinden in de bijbelse teksten: Hos 2:18-23. Urbach (1979:487-91) bespreekt de rabbijnse inzichten in de afhankelijkheid van de wereld van de gerechtigheid van de mensen; ze lezen Spr 10:25 als "Maar de rechtvaardige is de grondvesting van de wereld." Verder ook Patai (1967:155-156, en vooral het laatste hoofdstuk).

${ }^{9}$ In Deutero-Jesaja 54:7-10, na de rampen van de ballingschap herinnert God zich zijn verbond en vernieuwt hij zijn beloften (Jes 54:7-10). 


\section{Beeldspraak over oorlog en schepping}

waarin ongeluk en kwaad de bovenhand schijnen te krijgen kan Israël tot God klagen en hem smeken zijn overwinning opnieuw door te zetten (Pss 74; 89; Jes 51:9-11).

In de apocalyptiek wordt de strijd tegen Leviatan geprojecteerd naar een beslissend moment in de toekomst; de moeilijkheden van het ogenblik werden verstaan alsof we nu nog leven in de periode voor in plaats van na Gods overwinning: "Leviathan is still loose, and the absolute sovereignty of the absolutely just God lies ahead" (Levenson 1994:48). Verder is het belangrijk in gedachten te houden dat in apocalyptische teksten het beeld van Gods oordeel nauw verbonden is met Gods strijd (Kovacs 1995:238-240). ${ }^{10}$ Dit helpt om Openbaring 19:11, waar oorlog en oordeel verbonden zijn, correct te verstaan.

Tenslotte, schepping moet gezien worden als een beeld voor kosmische redding en de komst van Gods rijk. Het bijbelse beeld van schepping kan niet beperkt worden tot de technische dimensie (God als bouwmeester). De nadruk ligt zelfs niet op de ontologische dimensie (creatio ex nihilo), ${ }^{11}$ maar op de ethische en religieuze dimensie. De schepping is gericht op een morele wereld, op de overwinning over het chaotische, het destructieve, het onrechtvaardige, waardoor het leven in gemeenschap met God in al zijn volheid gerealiseerd kan worden. ${ }^{12}$ Daarom is oorlog als creatieve mogelijkheid nauw verbonden met rechtspraak en rechtshandhaving door middel van veroordeling en straf.

Het is daarom niet verwonderlijk dat de geschiedenis van Gods redding werd verstaan volgens het patroon van de scheppingsweek uit Genesis $1 .{ }^{13}$ De vroege kerk ontwikkelde dit traditionele thema verder en telde de eerste dag van de week, de dag van de verrijzenis, als de achtste dag, het begin van de nieuwe schepping (Barn. 15:3-9; Justinus, 1 Apol. 67; zie Hermans 1959). Dit kan belangrijk zijn om de vermelding van de dag van de Heer in

\footnotetext{
${ }^{10} 1$ En 1:3-9; 55:4; 4 Ez 12:33; 13:39; Dan 7-12; Op 19:11.

${ }^{11}$ We kunnen wel instemmen met Copan (1996:93): "So, contrary to May and others, the doctrine of creation out of nothing was not simply created ex nihilo by post-biblical theologians of the second century to counteract Gnostic ideas".

${ }^{12}$ Reventlow (2002:171) verwijst naar het werk van Francis Watson (1997): “The identity of creature and covenant- partner ... overcomes the dichotomy of creation and covenant, but as a dynamic ongoing reality. Both are still on the way and have an eschatological aim". Patai (1967:155) verwijst naar een aantal nuttige Rabbijnse teksten; volgens een tekst uit Pesiqta Rabbati: Rabbi Hiyya bar Abba zei in de naam van Rabbi Johanan: "de aarde zei (op het ogenblik dat God the Torah gaf aan Israel): 'Als Israel de Torah niet aanvaardt zal ik terugkeren in mijn waters zoals ik was'."

${ }^{13} \mathrm{Er}$ is overeenstemming tussen de overwinning over de oermonsters bij de schepping, de redding bij de uittocht uit Egypte (Ps 74:12-17) en de nieuwe uittocht uit Babylon (Jes 43:13$16 ; 43: 14-21 ; 51: 9-11)$.
} 
Openbaring 1:10 te begrijpen, de dag waarop Johannes zijn visioen kreeg van de verrezen Jezus, de eerste en de laatste, een visioen dat uitziet naar de vervulling van de schepping en dat de zeven gemeenten confronteert met het komende oordeel. ${ }^{14}$ Dit is precies wat de viering van de zondag wil oproepen.

\section{SCHEPPING EN OORLOG IN OPENBARING}

We zullen eerst de thema's van schepping en oorlog identificeren in het boek Openbaring en dan proberen te zien hoe het beeld van de oorlog functioneert als een middel waardoor de schepping zijn vervulling vindt.

God wordt geprezen als de schepper (Op 4:11; 10:6; 14:7) en Jezus is verbonden met de oorsprong van Gods schepping (Op 3:14). De schepping is echter bedreigd en Johannes toont hoe de Beesten en degenen die hun zijde kiezen, vooral Babylon, de aarde vernielen (Op 11:18; 19:2). ${ }^{15}$ De vestiging van het koninkrijk van God en van zijn Gezalfde zal de vernieling betekenen van hen die de aarde vernielen (Op 11:15-18, zevende trompet), vooral van Babylon (Op 16:19, zevende schaal). Het resultaat zal zijn de nieuwe hemel en de nieuwe aarde (Op 21:1, 5) en het nieuwe Jeruzalem met de kenmerken van het paradijs (de boom van het leven, de rivier, goud en edelstenen, zie Gen 2:9-14). Het verband tussen Jeruzalem en de nieuwe hemel en de nieuwe aarde kan men terugvinden in Jesaja 65:17-18. ${ }^{16}$ Verder moet men ook de traditie in acht houden volgens de welke de berg Sion of de stad Jeruzalem beschouwd werd als het deksel dat de aarde afschermt tegen de grote afgrond. ${ }^{17}$

De schepping was geen definitief en zelfs geen absoluut succes in die zin dat de elementen van de chaos (de zee en de duisternis) nog hun, zij het beperkte, plaats hadden. Verder moet de verwoestende invloed van de zonde in de geschapen wereld worden verdisconteerd. In de nieuwe schepping is er echter geen plaats meer voor de zee of de duisternis (Op 21:1, 23-25). Er zal geen dood meer zijn, want dit behoort tot de vroegere condities (Op 21:4), maar de inwoners van het nieuwe Jeruzalem zullen genieten van het water en

\footnotetext{
${ }^{14}$ Bacchiocchi (1977:111-134) probeert aan te tonen dat we hier niet te doen hebben met de Zondag, maar eerder en alleen met de komende Dag van de Heer, de Parousia.

${ }^{15}$ Dit herinnert aan Jeremia 51:25; daar ook is Babylon's vernieling van de aarde gecontrasteerd met God de Schepper (Jer 51:15-19); hij zal oorlog voeren door middel van Israel, Gods oorlogswapen (Jer 51:20-23).

${ }^{16}$ Levenson (1994:89-90) schrijft: "The reconstruction of the temple-city was not only a recovery of national honor, but also a renewal of the cosmos, of which the temple was a miniature."

${ }^{17}$ Levenson (1994:99) verwijst naar b.Suk. 53a-b en naar het werk van Raphael Patai (1967:54-59).
} 


\section{Beeldspraak over oorlog en schepping}

van de boom van het leven (Op 2:7; 7:17; $21: 6 ; 22: 1,2,14)$. Diegenen die de verbondsverhouding (Op 21:4,7) geschonden hebben zijn uitgesloten en ervaren de tweede dood in de poel die brandt van vuur en zwavel (Op 21:8). Daarmee heeft God, alpha en omega, begin en einde, uiteindelijk de oorlog tegen de chaos en het kwaad gewonnen en zijn schepping project tot voleinding gebracht (Op 21:5-6).

Het thema van de oorlog komt vaker voor in Openbaring dan in de rest van het NT. ${ }^{18}$ In Openbaring 9:7 en 9 worden de sprinkhanen bij de vijfde trompet vergeleken met oorlogspaarden. In Openbaring 11:7 voert het Beest uit de afgrond oorlog tegen de twee getuigen, overwint hen en doodt hen. In Openbaring 12 zijn het Michael en de Draak die oorlog voeren met elkaar, maar wanneer de Draak op aarde neergeworpen wordt voert hij oorlog tegen de vrouw en haar kinderen (Op 12:7,17). In Openbaring 13 wordt het Beest uit de zee voorgesteld als machtig in de strijd en het wordt hem toegestaan oorlog te voeren tegen de heiligen (Op 13:4,7). De zesde schaal is de voorbereiding voor de oorlog op de grote dag van God Almachtig: de wateren van de Eufraat drogen op en demonische geesten uit de mond van de Draak, het Beest en de valse Profeet verzamelen de koningen van de hele aarde voor de oorlog (Op 16:12-14). Het thema van de oorlog van de koningen verschijnt opnieuw in Openbaring 17:14, waar we horen van de toekomstige overwinning van het Lam. In Openbaring 19:11-21 vinden we het visioen van de oorlog en de overwinning op de koningen en de Beesten. Na de duizend jaar wordt de Draak vrijgelaten en hij begint onmiddellijk de volken te misleiden om deel te nemen aan een nieuwe oorlog, maar vuur uit de hemel maakt een abrupt eind aan die oorlog: de Draak eindigt in de poel van vuur en zwavel (Op 20:7-10). Dood en Hades ondergaan hetzelfde lot (Op 20:14). ${ }^{19}$

Het zwaard uit de mond van Jezus wordt verschillende keren vermeld: reeds in het openingsvisioen (Op 1:16) en verder als oorlogswapen tegen de leden van de gemeente in Pergamon (Op 2:12,16); tenslotte in de oordeelsen oorlogsscene tegen de vijandige koningen van de aarde (Op 19:11-21). Dit zwaard toont aan dat het niet gaat om een gewone, menselijke oorlog. Dit wordt onderstreept wannneer de finale oorlog gewonnen wordt door middel van vuur uit de hemel (Op 20:9).

Het semantisch veld van de oorlog is verder verrijkt door het thema van de overwinning. Het werkwoord vikó $\omega$ behoort tot dit veld en wordt gebruikt

\footnotetext{
${ }^{18}$ Het zelfstandig naamwoord en het werkwoord vindt men 15 keer in Openbaring en 10 keer in de rest van het NT.

${ }^{19}$ Het thema van de oorlog is een van de belangrijke verbindingen tussen de themas van schepping en uittocht, die beide zeer belangrijk zijn in Openbaring; zie Jes 51:9-11, waar de oorlog van de schepper herhaald wordt in Egypte, en opnieuw in de redding uit Babylon.
} 
om te verwijzen naar de tijdelijke overwinningen van het Beest $(11: 7 ; 13: 7)$, maar ook naar de blijvende overwinning van het Lam en zijn gevolg. ${ }^{20}$ Twee teksten verwijzen naar Jezus (Op 5:5 en 17:14). In de eerste tekst, 5:5, wordt de overwinning toegeschreven aan de Leeuw uit de stam Juda, maar wanneer de overwinnaar getoond wordt aan Johannes ziet hij een Lam dat geslacht was maar nu rechtop staat te midden van de troon en de 24 oudsten. Drie hymnen (Op 5:9-10,12,13b) gezongen door een al maar groter wordend koor ontwikkelen de betekenis van de overwinning. Het werkwoord oфá $\zeta \omega$ komt drie keer voor in Openbaring 5 (verzen 6, 9, 12) en toont aan dat de overwinning verbonden is aan de gewelddadige dood van het Lam. De tweede tekst, 17:12-14, kondigt een oorlog aan tegen het Lam, beraamd door de tien horens samen met het Beest, maar het Lam behaalt de overwinning. ${ }^{21}$ Het Beest is dus uiteindelijk machteloos tegen het Lam, want het Lam is de Heer der heren en de Koning der koningen; het heeft een superieure status die reeds geopenbaard en gevierd werd in het vijfde hoofdstuk van Openbaring. ${ }^{22}$

Elk een van de zeven brieven uit het begin van Openbaring eindigt met een aansporing om te overwinnen in de vorm van een belofte (Op 2:1, 11, 17, $25-28 ; 3: 5,12,21)$. De belofte en uitdaging wordt herhaald door Hem die op de troon gezeten is volgens Openbaring 21:7, waar de overwinnaars gecontrasteerd worden met "de lafhartigen, de trouwelozen, de verdorvenen, de moordenaars, de hoereerders, de tovenaars, de afgodendienaars, en alle leugenaars ..." ( 8 8). De aard van zowel de oorlog als de overwinning wordt verder uitgelegd in Openbaring 15:2: "die over het beest en zijn getal en zijn naam hadden gezegevierd." Met andere woorden, zij hebben geweigerd het Beest te aanbidden (Op 13). Openbaring 12:11 geeft verder inzicht in deze overwinning door aan te duiden dat de volgelingen reeds nu op aarde overwinnaars zijn door het bloed van het $\mathrm{Lam}^{23}$ en door hun geloofsbelijdenis. De kwaliteit van hun geloof toont zich in hun radicale toewijding, ${ }^{24}$ waarin ze

\footnotetext{
${ }^{20}$ De interpretatie van de ruiter op het witte paard in 6:2 is zeer omstreden. Ik verkies de interpretatie van Giesen (1997:176) die de ruiter ziet als een symbool voor de reddende tussenkomst van God en het Lam ten voordele van hen die trouw zijn; vergelijk Ezek 5:16-17.

${ }^{21}$ Op 17:12-14 contrasteert met Op 17:16-17, waar het is de vrouw die aangevallen wordt en overwonnen door de tien horens en het Beest volgens het plan van God; zie de Villiers 2002:116.

${ }^{22}$ De oorlog in 19:11-21 tegen het Beest en de koningen breidt de scene van deze verzen verder uit: Jezus is opnieuw voorgesteld als de Koning der koningen en de Heer der heren (v16).

${ }^{23}$ Volgens Op 5:9 zijn ze bevrijd van slavernij, vrijgekocht door het bloed van het Lam; volgens Op 7:14 zijn ze gezuiverd door het bloed (zie Van Schaik 1971:136).

${ }^{24}$ Gebrek aan radicale toewijding is misschien aangeduid in de uitdrukking dat de werken van de gemeente van Sardis niet $\pi \varepsilon \pi \lambda \eta \rho \omega \mu^{\prime} \varepsilon v \propto$ zijn (Op 3:2).
} 
bereid zijn zelfs hun leven te verliezen, zoals Jezus, die hen bemind had tot de dood (Op 1:5).

Openbaring 2:26 verbindt "overwinnen" met "volharden tot het einde in het doen van de werken van Jezus" als uitdrukking van hun radicale toewijding, hun trouw tot de dood (Op 2:10) (Decock 2007:49-53). ${ }^{25}$ Het is wel betekenisvol dat de metaforen van oorlog en werk hier samengebracht worden. Openbaring 3:21 toont verder de gelijkenis tussen de overwinning van Jezus en die van zijn volgelingen. Voor de volgelingen echter sluit overwinning ook bekering in, waarbij ze vermijden door Jezus gestraft te zullen worden (Op 2:5, 16, 21-23; 3:3, 19); bekering is ook te omschrijven als een zich afkeren van de werken van Satan (Op 2:22; 9:20; 16:11). ${ }^{26}$

\section{HET LAM EN DE LEEUW}

$\mathrm{Er}$ is al veel geschreven over het feit dat in Openbaring 5:5-6 de overwinning van de Leeuw van de stam Juda aangekondigd wordt, terwijl Johannes een Lam ziet dat geslacht was. Moyise (2001:181-182) verwijst naar de interpretaties van Caird, Sweet, Boring, Bauckham, en Beale, die allemaal op een of andere manier de opeenvolging Leeuw - Lam verstaan als een poging van Johannes om de traditioneel Joodse Messias te herdefiniëren in termen van een lijdende en zichzelf slachtofferende Messias. Moyise (2001:182) vraagt dan echter: "But is such a theology really to be found in the book of Revelation?" Inderdaad, het Lam was geslacht (Op 5:6, 9, 12; 13:8), maar nu staat het rechtop (verrezen), in het midden van de troon van God; het heeft zeven horens en zeven ogen (Op 5:6). Zijn aardse leven was inderdaad

\footnotetext{
${ }^{25}$ Middleton (2006) vindt in Openbaring een eerste getuigenis van wat hij noemt "radical martyrdom", wat betekent, actief arrestatie en executie zoeken. Hij ziet dit niet als een phenomeen van een paar ketters hier en daar, maar als "a prevalent and, indeed, idealized form of Christian attitude to death from the late first to the early third centuries" (Middleton 2006:172). De aansporing om te overwinnen in Openbaring "always denotes a call to achieve death through martyrdom. Moreover, that call to conquer is made to all Christians" (Middleton 2006:161). Middleton interpreteert de verwijzing naar het "aantal" martelaren bepaald door God (Op 6:11) als een aanduiding dat Johannes zijn lezers en toehoorders aanmoedigt zich over te geven om de marteldood te sterven en zo Gods oordeel te bespoedigen. Daartegen zien we dat ditzelfde thema voorkomt in 4 Ez 4:35-37, waar het niet deze functie heeft "radical martyrdom" aan te moedigen. In elk geval, in Openbaring is de uitdaging niet de dood na te streven maar trouw te blijven tot in de dood.

${ }^{26}$ Middleton (2006:128-134) situeert martelaarschap in de Joodse traditie van de heilige oorlog, maar voor hem is het verschil tussen de Joodse en de Christelijke beschouwing van de heilige oorlogstraditie als volgt: de Christenen "never had an army or a homeland, and so no possibility for revolt ever existed. It was the same apocalyptic war tradition of the Jews, but for the Christian it was immediately spiritualized, universalized and transferred to the cosmic realm" (Middleton 2006:133). Middleton verbindt de heilige oorlog en de cosmische dimensie niet met de schepping zoals die nu is. De oorlog is over de toekomst van Gods schepping. Middleton's zicht op de verhouding van de Christen tot de wereld is wazig waar hij eenvoudigweg beweert: "There was no earthly battle to be won, no earthly outcome to be desired, other than the Christian's escape from the world" (Middleton 2006:133).
} 
gekenmerkt door liefde en zelfopoffering tot in de dood, maar daarom is hij nu verheerlijkt met "macht en rijkdom, wijsheid en kracht, en eer en heerlijkheid en lof" (Op 5:12) om het werk van de schepping te voltooien als rechter en veldheer (Op 19:11). De toorn van God en van het Lam is een vreesaanjagend vooruitzicht voor de mensheid (Op 6:16-17).

Het Lam is een slachtoffer maar tegelijkertijd is het ook machtig. ${ }^{27}$ Deze twee aspecten zijn logisch met elkaar verbonden; het eerste leidt naar het tweede zoals ook in Jesaja $53 .^{28}$ Jezus' dood en verrijzenis zijn een overwinning waardoor hij waardig bevonden wordt het boek met de zeven zegels te openen (Op 5:5) en zo Gods plan met de schepping te voltooien. Jezus' machtspositie is voorgesteld in termen van bevoegdheid om te oordelen en macht om oorlog te voeren. De twee horen nauw samen want oordeel zonder macht van executie is waardeloos. ${ }^{29}$ De martelaren onder het altaar (Op 6:10) roepen luid om oordeel en bloedwraak: oú kp'iveıs kờ

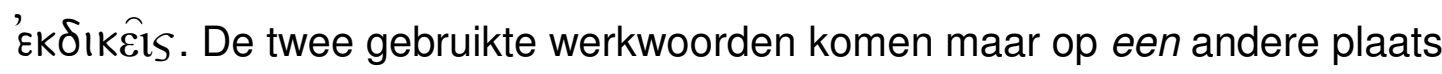
in Openbaring samen voor, in Openbaring 19:2, wanneer de grote menigte in de hemel de verwoesting van Babylon herkent als het antwoord op dit gebed. Ze erkennen en verkondigen dat Gods oordelen waarachtig en rechtvaardig zijn. ${ }^{30}$ Daarna wordt het perspectief op het kwaad in de schepping verbreed, van het bloed van de martelaren tot de dreigende verwoesting van de hele aarde (Op 19:2). Een tweede koor (Op 19:6-8) verschuift de focus, van de negatieve handeling (verwoesting van Babylon) naar de positieve (de vestiging van Gods koninkrijk en het bruiloft van het Lam). Op deze manier is de bloedwraak van de martelaren duidelijk verbonden met de vestiging van het koninkrijk van God in heel de schepping door het oordeel en de strijd van het Lam. Het Lam als slachtoffer was de eerste etappe van zijn reddingswerk; het is de weg die de gemeenten moeten volgen. In de volgende etappe, als herder, rechter en strijder, als de Leeuw van de stam Juda, als de Wortel van David, zal hij de schepping bevrijden en de vervulling van al Gods beloften mogelijk maken. ${ }^{31}$ De tweede etappe stimuleerde de hoop van de gemeenten;

\footnotetext{
${ }^{27}$ Het Lam in Openbaring brengt twee tradities samen, het Lam als leider en als slachtoffer (Aune 1997:367-373).

${ }^{28}$ Jes 52:13-53:12 heeft als thema de verheerlijking als een inclusio: Jes 52:13-15 en 53:11c12: het contrast tussen de huidige verheerlijking en de vroegere vernedering.

${ }^{29}$ In Daniël 7 is het beeld van het oordeel dominerend (Dan 7:9-11, 26) en de executieve macht is eenvoudigweg verondersteld.

30 "Waar en rechtvaardig" komt ook voor in Op 15:3 (Gods wegen); 16:7 en 19:2 (Gods oordelen); zie ook 19:11. Vergelijk met Jes 11:5.

${ }^{31}$ Jesus, het Lam, is de herder die zijn getrouwen leidt (Op 7:16-17); hij is ook de herder die de volken zal weiden met een ijzeren staf (Op 12:5; 19:15).
} 
de eerste etappe bepaalt de concrete manier waarop de gemeenten geroepen zijn om te strijden en te overwinnen.

\section{DE SPANNING TUSSEN JEZUS ALS HET GESLACHTE LAM EN ALS HET MACHTIGE, TOORNIGE, ANGSTAANJAGENDE LAM}

Neville (2007:153) heeft de aandacht gevestigd op de "inherent tension between Matthew's violent eschatology and his depiction of the non-violent moral vision of Jesus grounded in the indiscriminate love of God." Hij verwijst naar Matteüs 5:43-48 waar de leerlingen aangespoord worden God na te volgen, God die "immers de zon laat opgaan over slechten en goeden en het laat regenen over rechtvaardigen en onrechtvaardigen." Maar, het eschatologisch geweld in Matteüs gaat daar volledig tegen in. De hemelse Vader op het einde van de parabel over vergiffenis (18:23-35) is helemaal niet vergevingsgezind, integendeel. Neville (2007:147) noemt het "obscene". ${ }^{32}$ Hoe kunnen we die tegenstrijdigheid het beste interpreteren? Vanuit zijn hermeneutisch standpunt kiest Neville ervoor om de onbekende vorm van Gods eschatologisch oordeel in Matteüs te interpreteren in het licht van de bekende niet-gewelddadige houding van Jezus. ${ }^{33}$

Voor het boek Openbaring moeten we vragen of we daar een gelijksoortige spanning vinden. We kunnen vier contexten onderscheiden: (1) Jezus' werk op aarde, waarin Openbaring vooral aandacht geeft aan zijn dood; (2) Jezus' hemelse functie waarin hij de reeksen van plagen ontketent; (3) Jezus' hemelse functie waarin hij de gemeenten uitdaagt of aanmoedigt; (4) de eindstrijd en het oordeel.

1. Jezus' liefde tot de dood toe $(\mathrm{Op} 1: 5 ; 5: 9,12 ; 11: 8)$ is het middel en het model voor een even radicale toewijding aan God bij de gemeenten (Op 1:5-6). Exclusieve aanbidding van God staat centraal in Op 14:6-7 en dat is het hart van de overwinning waartoe alle mensen opgeroepen worden.

\footnotetext{
${ }^{32}$ Neville (2007:152) ziet dit eschatologisch geweld als "a form of idolatry, constructing God in our image rather than vice versa; but perhaps a better term for this is blasphemy, for what could be worse than projecting on to God our basest and most unimaginative quality?"

33 "In other words, the story Matthew told contains within itself the wherewithal to deconstruct his own eschatological outlook. Thus part of our hermeneutical task is to desist from prejudging, and thereby pre-empting, the form divine judgment might take, which when all is said and done, might turn out to display more of the Creator's inexhaustible creativity than anyone could have imagined" (Neville 2007:158).
} 
2. In zijn hemelse functie (zegels, trompetten, schalen) confronteert Jezus de bewoners van de aarde eerder met geweld om hen tot God te bekeren. De rampen en plagen moeten gezien worden in het licht van de relatie tussen menselijke zondigheid en de vernietiging van de schepping. ${ }^{34}$ Bekering tot de ware God is een kwestie van leven en dood voor de mensheid, maar ook voor de schepping zelf.

3. De verrezen Jezus gebruikt soms gewelddadige taal in zijn oproepen aan de gemeenten, met de bedoeling om hen tot bekering te brengen (Op 2:16, 22-23). Dit is opnieuw een aspect van de profetische taak.

4. De eindstrijd en het oordeel. De oorlog treft eerst en vooral de chaotische machten, de Draak en de Beesten, maar ook iedereen die hen aanbidt, iedereen die zich afkeert van de aanbidding van God. De Draak wordt in Openbaring 12 voorgesteld als zeer destructief, maar ook als voortdurend gefrustreerd, en "ziedend van woede omdat hij weet dat zijn dagen geteld zijn” (Op 12:12). De oorlogen zijn het initiatief van de Draak en zijn Beesten; de acties van God en Jezus vormen het antwoord op hun agressie. Gods vijanden worden geëlimineerd, maar geleidelijk: eerst Babylon, dan de twee Beesten, en uiteindelijk de Draak, de Dood, de Hades, de Zee en de Duisternis.

De brandende vragen die het boek Openbaring moet beantwoorden zijn: hoe lang duurt het voordat het oordeel komt (Op 6:10), en waarom treedt God niet onmiddellijk op tegen de chaotische krachten die de aarde vernielen (Op 11:18; 19:2)? God zou direct kunnen optreden, op volle kracht, maar er is uitstel: de profetische taak moet eerst nog "voor een korte tijd" verder gaan ondanks vervolging en levensverlies (Op 6:9-11). Het door God bepaalde aantal martelaren dat eerst bereikt moet worden bestaat uit hen die in dienst staan van "het woord van God en het getuigenis dat ze hebben" (Op 6:9). De profetische taak van de gemeenten moet nog gedurende een door God bepaalde tijd verder gaan. ${ }^{35}$ Het lijden van de getuigen is het gevolg en de

\footnotetext{
${ }^{34}$ Volgens Patai (1967:149-152) zag de Rabbijnse traditie drie zonden als bijzonder schadelijk voor de schepping: afgodendienst, ontucht, en bloed vergieten. Die drie worden zeer regelmatig vermeld in Openbaring en zijn ook zeer nauw verbonden: Op 9:20-21; $21: 8$; $22: 15 ; 6: 10 ; 16: 6 ; 17: 6 ; 18: 24 ; 2: 14,20,21 ; 9: 21 ; 14: 8 ; 17: 1$, 2, 5, 15,16; 18:3, 9; 19:2. Deze laatste tekst verbindt de vernietiging van de aarde uitdrukkelijk met de ontucht.

${ }^{35}$ Het getuigenis verwijst naar de profetische dienst, zie Op 11:7 in het licht van Op 11:3, waar de twee getuigen zullen profeteren, en van 11:10, waar de twee getuigen nu twee profeten zijn.
} 


\section{Beeldspraak over oorlog en schepping}

uitdrukking van Gods grootmoedigheid en geduld. ${ }^{36}$ God volhardt in het zenden van zijn profeten en doet zijn oproep tot bekering uitgaan ondanks de gewelddadige verwerping van deze profeten (Mark 12:1-12). ${ }^{37}$

Bekering en exclusieve aanbidding van God (Op 19:10; 22:9) door alle bewoners van de aarde zou God in staat stellen de chaotische machten te elimineren zonder ook maar een van de wereldbewoners te verliezen. Openbaring is hoopvol en toch ook bezorgd voor de gemeenten; dit is uitgedrukt in de herhaalde belofte en aansporing op het einde van de brieven: "Wie overwint ..." Een gelijksoortige hoop voor alle bewoners van de aarde is verwoord, maar minder expliciet, in het gegeven dat koningen en volken, vroeger volgelingen van het Beest, zullen toetreden tot het nieuwe Jeruzalem (Op 21:24-26; 22:3). Maar de mogelijkheid blijft ook open dat niet iedereen zich afkeert van de Draak en zijn Beesten en daardoor hun lot zal delen (Op 20:15).

\section{GOD EN GEWELD}

Het huidige wereldbewustzijn is zeer gevoelig voor misbruik van macht en nodeloos geweld. Een "rechtvaardige oorlog" wordt in veel gemeenschappen aangevoeld als een oxymoron. Straf voor misdaden wordt eufemistisch voorgesteld als correctie door "correctieve diensten." Hoe kan men zich in deze tijd voorstellen dat God het project van de schepping juist door middel van oorlog en oordeel tot een goed einde zal brengen? Moet God het niet kunnen zonder geweld en zonder straf?

Dit zijn echter niet de vragen van het boek Openbaring. Evenals in de rest van de Bijbel wordt God spontaan gezien als een God van liefde en toorn: van toewijding aan de schepping, van geweld en bestraffing van onrecht of ontrouw, maar ook van medelijden en vergiffenis (Hos 11:1-11). De metaphorische voorstelling van Gods scheppende actie als oorlog tegen alle chaotische machten volgt de lijn van een lange profetische en apocalyptische traditie (Hanson 1975:300-23). Voor Hanson is de functie van deze mythologische voorstellingen een manier van spreken over dimensies van

\footnotetext{
${ }^{36}$ In 2 Petrus 3:1-15 is het uitstel gezien als een uitdrukking van Gods geduld: "daar hij wil dat allen to inkeer komen en niemand verloren gaat" (v 9); zie ook Romeinen 11:32; 1 Timoteüs 2:4-6. Volgens Markus 13:9-13 moet de prediking aan de heidenen, met vervolging, voorafgaan aan de wederkomst. In Romeinen 11:25-26a is het vooraf bepaalde aantal ook verbonden aan Gods heilsplan om uit te reiken naar de heidenen zowel als naar Israel. Barr (2003:102) ziet het wachten niet als tijd voor de verkondiging maar als tijd van wachten tot het kwaad zich zelf vernietigt.

${ }^{37}$ Bauckham (1993:273-283) heeft geprobeerd om aan te tonen dat het verhaal van de twee getuigen (Op 11:1-13) precies wil laten zien hoe het dreigende en vernietigende vertoon van macht van de getuigen niet in staat is om mensen tot bekering te brengen. Alleen trouw getuigenis tot de dood (Op 2:10), naar het voorbeeld van Jezus (Op 11:18), zal bekering bewerken (Op 11:13, zie 14:7; 15:4).
} 
goddelijk handelen die niet verstaan en uitgedrukt kunnen worden in termen van menselijke, historische instrumentaliteit. ${ }^{38}$ Dit teruggrijpen op mythologische gegevens is een soort theologia negativa, die reageert op de deuteronomistische theologie van de geschiedenis, waar God's handelen in de geschiedenis logisch en helder kon worden verklaard. ${ }^{39}$ Hetzelfde kan ook gezegd worden van Gods oorlog; hoe precies God het kwade zal overwinnen en de schepping tot vervulling brengen is uitgedrukt in symbolische voorstelling en in die zin ook verborgen in geheimenis.

Verder wordt deze metaforische voorstelling van de scheppende actie in het boek Openbaring gebruikt als een antwoord op de mythe van het Romeinse Imperium als goddelijk instrument voor de vernieuwing van de wereld in de Pax Romana (Friesen 2004; Barnett 1989). Oorlog en vestiging van koninklijke macht waren in de politieke omstandigheden van die tijd voor de hand liggende beelden om zich voor te kunnen voorstellen hoe God zijn rijk van rechtvaardigheid zou doorzetten in een wereld van onrecht en geweld. Ook de traditionele opvatting van bestraffing als een spectaculair afschrikkingsmiddel speelt een belangrijke rol. Hoewel God's machtsvertoon in de beeldspraak veel gelijkenis vertoont met de macht van het Romeinse Imperium, is God in feite niet alleen veel machtiger, maar ook volstrekt anders. De Romeinse macht is voorgesteld als vernielend, vooral door hun afgodendienst, hun ontucht en hun bloed vergieten (zie voetnoot 35). God's macht en gebruik van dwang worden voorgesteld als een bescherming van de schepping en van het recht. ${ }^{40}$ Verder is de goddelijke macht gekenmerkt door gevoel voor proportie, rechtvaardigheid, ${ }^{41}$ en vooral ook door geduld, (het "korte uitstel" Op 6:11), waardoor God, ten koste van het bloed van zijn profeten, aan alle bewoners van de aarde ruimte biedt voor bekering.

\footnotetext{
${ }^{38}$ Hanson zag dit eerder als een negatieve ontwikkeling vergeleken met de profetische eschatologie, een soort wegglijden van geschiedenis naar mythe en cosmologie. Maar deze tegenstelling tussen een God die werkt in de geschiedenis met mensen en een God die werkt als Schepper van de wereld en de mensen kan niet meer aanvaard worden. Geloof in God als Schepper is geen late ontwikkeling onder vreemde invloed. Zie de discussie in Reventlow (2002).

${ }^{39}$ Hanson (1975:310) vraagt zich af: "Could a theologoumenon which taught that Yahweh's actions and intentions would be discerned directly and transparently within the events of history sustain a faith in a period when contemporary historical events suggested Yahweh's indifference to Israel's fate or even his impotence to save?"

${ }^{40}$ Zoals Gottwald (1976:944) het uitdrukt, verwachtte de vroege Kerk "an impending eruption of an overwhelming and just power that would reconstitute human societies as the single society of the divine warrior through the agency of his triumphant Son."

${ }^{41}$ Het "geweld" van God is ook voorgesteld als redelijk en volgens de maat van de misdaden (Op 11:18; 16:6; zie Decock 2004:171-72).
} 


\section{Beeldspraak over oorlog en schepping}

Is het beeld van Gods oorlog in Openbaring geen indirecte aansporing tot geweld $?^{42}$ Ondanks het feit dat Openbaring de reputatie heeft van een gewelddadig boek worden de christenen helemaal niet aangespoord geweld te plegen maar eerder tot deelname aan de strijd van de aardse Jezus: tot het doen van de werken van Jezus (Op 2:26; 14:12) en het afleggen van getuigenis over hem tot in de dood (Op 12:11). Pas daarna, na hun marteldood, zullen ze deel hebben aan de macht en het oordeel (Op 20:4) en de oorlog (Op 19:14) samen met de verheerlijkte Jezus. Deze machten zijn voorbehouden aan het hemelse domein. Ze behoren uitsluitend in Gods handen, zoals het ook is uitgedrukt in Romeinen 12:19. "Mij komt de wraak toe." Toorn, macht, en straf als zodanig worden niet veroordeeld, maar alleen God weet hoe ermee te werken, terwijl ze in de handen van mensen een gevaar zijn. ${ }^{43}$

Openbaring 11:5-6 lijkt daarom een problematische tekst te zijn, maar hun geweld is "goddelijk" geweld, in die zin dat het hun gegeven is voor een beperkte tijd op te treden als instrumenten van God's macht. De twee getuigen hebben bovennatuurlijke kracht ontvangen om door het vuur uit hun mond hun tegenstanders te vernietigen, en dit gedurende een beperkte tijd, de 1260 dagen van hun profetische dienst (zie Jer 5:14; ook 4 Ezra 13:8-11, 27-38). Verder hebben ze ook voor de tijd van hun dienst de vernietigende macht die enkele profeten typeerde. ${ }^{44}$ Dit is de vernietigende macht die de hemelse Jezus ontplooit met de zeven zegels, de zeven trompetten, en de zeven schalen. Het belangrijke echter is zien dat er twee soorten geweld zijn, menselijk en goddelijk geweld. Menselijk geweld is absoluut verboden door de Wet en ook veroordeeld in Openbaring (Op 16:6; 21:8; 22:15). Dit soort geweld ondermijnt de schepping. Goddelijk geweld daarentegen beschermt de schepping. Het neemt twee vormen aan, rechtspraak en oorlog (Op 19:11). De eerste vorm werkt nu al in onze wereld door de menselijke rechtspraak (Rom 13:1-4), maar wordt voltooid voor de troon van God (Op 20:11-15). De tweede vorm, oorlog, werkt ook nu al in onze wereld door de profeten, maar in beperkte maat, zoals in Openbaring 11:5-6. Deze vorm van geweld is duidelijk van bovenmenselijke oorsprong en is buiten menselijke controle. We vinden een goed voorbeeld van deze tegenstelling tussen menselijk en bovenmenselijk geweld in Johannes 18:1-11, waar Petrus met het zwaard toeslaat en berispt wordt door Jezus, terwijl een bovenmenselijke kracht

\footnotetext{
${ }^{42}$ Volgens Christopher Rowland (2003:4), “... the Apocalypse has only rarely been directly linked with the promotion of violence ...".

${ }^{43}$ Zoals Lactantius het uitdrukte met verwijzing naar Ef 4:26, "de toorn van stervelingen moet sterfelijk zijn" (Ir. 21:5-6).

${ }^{44}$ Eks 7-15; Num 16; 25; 1 Kon 17:11-16; 18; 2 Kon 1; 2:23-25; Jer 1:10; 28 . Allison (2002:459-478) toont aan dat er een Joodse en vroeg Christelijke traditie was die het geweld van sommige van die teksten in vraag stelde.
} 
uitgaat van de woorden van Jezus waardoor de soldaten en hun helpers op de grond neervielen. ${ }^{45}$ Deze "wonderbare" vorm van geweld is onder Gods controle en is een goddelijk teken. ${ }^{46}$

Alhoewel de twee getuigen machtig en zelfs gewelddadig zijn gedurende de tijd van hun profetische dienst, zijn ze uiteindelijk toch machteloos en sterven ze, zoals Jezus, de martelaarsdood (Op 11:7-9). Als profeten worden ze gezien als lijdende figuren (Luk 11:47-51; 13:34), een conditie van machteloosheid die Jezus zelf op zich genomen heeft. Het is dit aspect van Jezus' aardse leven dat Openbaring benadrukt en dit wordt uitgedrukt in de verwijzingen naar Jezus' "slachting" (Op 5:6, 9, 12; 13:8) en vooral naar Jezus' bloed (Op 1:5; 5:9; 7:14; 12:11). Jezus' macht wordt getransformeerd tot toewijding en liefde: het Lam is ook de herder die zijn leven geeft, zoals in Johannes 10:11-18. Dit is dan ook het beeld van Jezus in het boek Openbaring: liefde en bloed zijn de weg van Jezus op aarde (Op 1:5; $5: 6,9,12)$; het is de vorm waarin zijn macht zich toont en dat is het model voor de gemeenten, een model dat de martelaren al hebben nagevolgd (Op 12:11). De oproep van het boek Openbaring aan de gemeenten is dan ook het geslachte Lam te volgen in zijn trouw aan God en in zijn liefde ${ }^{47}$ tot in de dood, gesterkt door de hoop op de uiteindelijke overwinning van het Lam (Op 19:11-16; 20:7-10). Hun vrijheid van zonde door het bloed van het Lam brengt welzijn voor Gods schepping waarin ze koningen en priesters worden voor God (Op 1:5-6; 5:9-10; 7:14-17; 12:10-11). Ondertussen moeten ze volharden in hun getuigenis; hun lijden is de keerzijde van Gods geduld met de wereldbewoners.

\section{CONCLUSIE}

De beeldpraak van God's oorlog en oordeel is een symbolische uitdrukking van Gods macht en toewijding waardoor God de schepping uiteindelijk tot voltooing zal brengen ondanks de chaotische machten. In de visie van Openbaring is de schepping in gevaar door de zonden van de bewoners van de aarde, waardoor ze meewerken met de chaotische machten die de aarde vernielen. Het "scheppende" geweld van God is dus zeer duidelijk onderscheiden van het "vernielende" menselijk geweld. De gemeenten in hun profetische taak delen in de goddelijke macht en geweld met het oog op de

\footnotetext{
${ }^{45} 4$ Ez 13:9-10 contrasteert vuur met de gewone oorlogswapens.

${ }^{46}$ De tekenwaarde van dit geweld is uitdrukkelijk aangeduid in Openbaring 2:23: "al de gemeenten zullen weten ...". De dood van Ananias en Saffira in Hand 5:1-11 moet ook in die zin verstaan worden; het resultaat is "grote vrees" (verzen 5 en 11). Jezus' weigering om vuur uit de hemel te laten neerkomen (Luk 9:54-55) is niet zozeer geinspireerd door een ideaal van geweldloosheid als door Jezus' oordeel dat het toen niet de juiste tijd was; die tijd zou later komen, zoals in Openbaring 20:9.

${ }^{47}$ Liefde is belangrijker in Openbaring dan meestal gedacht wordt (zie de Villiers 2007).
} 


\section{Beeldspraak over oorlog en schepping}

bekering van de bewoners van de aarde (Op 11:5-6), maar deze macht is beperkt; de gemeenten zijn uiteindelijk lijdende figuren zoals de profeten, en zelfs nog radicaler, zoals Jezus. Deze beperking is deel van Gods "uitstel" waardoor het "scheppende" geweld van God wacht totdat de door God bepaalde maat voor de profetische dienst van de gemeenten vervuld is. Deze dienst is gegrond op Jezus, de trouwe getuige, die door zijn bloed mensen bevrijdt uit het vernielende geweld van de zonde. Hij maakt hen bekwaam om God als priesters te dienen en doet hen delen in Gods koningschap. Hun strijd en overwinning bestaat erin vast te houden aan de werken van Jezus tot het einde, want deze werken zijn in harmonie met het welzijn van de schepping. Terwijl Gods geweld wacht verkondigt het boek Openbaring dat christenen door middel van de werken van Jezus, zijn liefde en zijn bloed, het menselijke geweld, dat de schepping vernielt, als het ware moeten absorberen.

\section{Geciteerde literatuur}

Allison, D C Jr 2002. Rejecting violent judgment: Luke 9:52-56 and its relatives. JBL 121, 459-478.

Aune, D E 1997. Revelation 1-5. Dallas, TX: Word. (WBC 52A.)

Barnett, $\mathrm{P}$ 1989. Polemical parallelism: Some further reflections on the Apocalypse. JSOT 35, 111-20.

Barr, D L 2003. Doing violence: Moral issues in reading John's Apocalypse, in Barr, D L (ed), Reading the Book of Revelation: A resource for students, 97-108. Atlanta, GA: SBL. (Resources for Biblical Study 44.)

Bauckham, R 1993. The climax of prophecy: Studies on the Book of Revelation. Edinburgh: T \& T Clark.

Bacchiocchi, S 1977. From Sabbath to Sunday: A historical investigation of Sunday observance in Early Christianity. Rome: Pontifical Gregorian University Press.

Collins, A.Y. 1976. The combat myth in the Book of Revelation. Missoula, MT: Scholars Press. (HDR 9.)

Collins, J J 2003. The zeal of Phinehas: The Bible and the legitimation of violence. JBL 122, 3-21.

Copan, P 1996. Is Creatio ex nihilo a post-biblical invention?: An examination of Gerhard May's proposal. TJ 17, 77-93.

Decock, P B 2004. The symbol of blood in the Apocalypse of John. Neot 38, 157182.

Decock, P B 2007. The works of God, of Christ, and of the faithful in the Apocalypse of John. Neot 41, 37-66.

De Villiers, P G R 2002. The composition of Revelation 17 and its place in the book as a whole. Acta Patristica et Byzantina 13, 97-119.

De Villiers, P G R 2007. Divine and human love in the Revelation of John. Acta Patristica et Byzantina 18, 43-59.

Friesen, S J 2004. Myth and symbolic resistance in Revelation 13. JBL 123, 281-313.

Giesen, H 1997. Die Offenbarung des Johannes. Regensburg: Verlag Friedrich Pustet. (RNT.)

Gottwald, N 1976. s v War, Holy. IDBSup. 
Hanson, P D 1971. Jewish apocalyptic against its Near Eastern environment. $R B$ 78, 31-58.

Hanson, P D 1975. The dawn of apocalyptic. Philadelphia, PA: Fortress.

Hanson, P D 1976. s v Apocalypticism. IDBSup.

Hermans, A. 1959. Le millénarisme du Pseudo-Barnabé. ETL 35, 849-76.

Hiebert, Th 1992. s v Warrior, Divine. $A B D$.

Kovacs, J L 1995. "Now shall the ruler of this world be driven out": Jesus's death as cosmic battle in John 12:20-36. JBL 114, 227-247.

Levenson, J D 1994. Creation and the persistence of evil: The Jewish drama of divine omnipotence, $2^{\text {nd }}$ ed. Princeton, NJ: Princeton University Press.

Middleton, P 2006. Radical martyrdom and cosmic conflict in Early Christianity. London: T \& T Clark. (Library of New Testament Studies 307.)

Moyise, S 2001. Does the lion lie down with the lamb? in Moyise, S (ed), Studies in the Book of Revelation, 181-194. Edinburgh: T\&T Clark.

Neville, D J 2007. Towards a teleology of peace: Contesting Matthew's violent eschatology. JSNT 30, 131-161.

Oden, R A 1992. s v Cosmogony, Cosmology. Anchor Bible Dictionary.

Patai, R 1967. Man and temple in ancient Jewish myth and ritual. $2^{\text {nd }}$ ed. New York: KTAV.

Reventlow, H G 2002. Creation as a topic in biblical theology, in Reventlow, H G \& Hoffman, Y (eds), Creation in Jewish and Christian tradition, 153-171. London: Sheffield Academic Press. (JSOTSup 319).

Rowland, C 2003. Apocalypse and violence: The evidence from the reception history of the Book of Revelation. Grace \& Truth: A journal of Catholic reflection for Southern Africa 20, 4-20.

Skaggs, R \& Doyle, Th 2007. Violence in the Apocalypse of John. Currents in Biblical Research 5, 220-34.

Urbach, E E 1979. The sages: Their concepts and beliefs. Translated from the Hebrew by I Abrahams. Jerusalem: Magnes.

Van Schaik, A P 1971. De Openbaring van Johannes. Roermond: Romen. 